\title{
COUNTING GAINS TO BEYOND ZERO-IMPACT FUTURES
}

\author{
DELWYN G. JONES ${ }^{1}$, SHLOKA ASHAR ${ }^{1}$, MATHILDE A. M. VLIEG ${ }^{1} \&$ DAVID M. BAGGS ${ }^{2}$ \\ ${ }^{1}$ The Evah Institute, Australia \\ ${ }^{2}$ Global GreenTag Pty Ltd, Australia
}

\begin{abstract}
The paper provides learning about past failures in the uptake of sustainability imperatives from qualitative discourse analysis of selected public communication, from reviewing a novel framework and from case studies in one scientific field. Resultant concepts, strategies and solutions are offered with potential to quell emerging threats and facilitate ecological remediation. Life cycle assessments (LCA) of certified ecolabelled and business as usual production systems with comparable spatiotemporal resolution and uncertainty were reviewed. Life cycle impact assessment (LCIA) frameworks cover damages to supply, climate, habitat and human health loss. With a negative range stopping at zero, LCIA excludes positive gains in supply, climate, human and habitat security. Results of risk and benefit analysis considering strength, weakness, opportunity and threat for sustainability reporting exposed gaps creating chasms in communications. In response Evah Associates compiled the life cycle benefit assessment LCBA2020 framework for positive development. LCBA methods were developed to quantify gains in regeneration and reparation of supply, climate, habitat and wellness within planetary boundaries safe operating space. Methods were tested to supplement third party verified LCA of real-world lumber, paper, personal care and recycling product for certified ecolabels as well as whole buildings as-built and as-designed. Benefit and damage metrics are compared for supply, climate, human and habitat outcomes. Results are also shown as carbon drawdown ratings and circularity scores useful for circular economy and United Nations sustainable development goals. The work concludes LCA is one of many impactful methods counting negativity that fails to engage people or quantify sustainability. Recommendations include that positive climate and habitat security narratives can be made compelling. Proof of competitive advantage requires quantification of benefits minus burdens. Justification of investment demands reporting of gain versus loss inside planetary boundaries. Finally, it is an imperative to engage people in counting benefits and gains.
\end{abstract}

Keywords: sustainability, metrics, benefits, positive, damage, climate brake, carbon bank., security.

\section{INTRODUCTION}

The 2019 United Nations (UN) state of environmental report [1] emphasizes urgent and inclusive action needed to achieve a healthy planet with healthy people. The UN has long instigated plans for nations to cut climate-degenerating dependencies and curb carbon budgets to zero global warming potential (GWP) [2], [3]. Establishing sustainable markets demands transformation to regenerative supply across all jurisdictions [4].

For almost half a century worldwide, however, global calls for action and market transformation plans have failed to redress loss of biodiversity and climate viability [2]. Relentless disinformation has derided and derailed sustainability imperatives [5].

Links between drought, heat waves, wildfires and climate change are well-known as are the significant risks posed for this planet's driest inhabited continent [1], [3]. The Australian Commonwealth Science and Industrial Research Organisation [6] reports fugitive methane from oil, coal and natural gas production accounts for $6 \%$ of national greenhouse emissions. In 2018, Australia was the world's largest exporter of coal and natural gas [7], [8]. Despite synergistic risks of drought, heat waves, high fuel loads, dry lightning ignition and megatonnes of flammable methane in the local landscape Australia remains economically dependent on extracting, using and exporting fossil fuels. 


\section{BACKGROUND}

This section aims to bring patterns of language, imagery and metrics relating climate and habitat into focus for closer examination. Selected extracts from global headlines between 2 December 2019 to 4 February 2020 relate verbal, written and visual examples.

\subsection{United Nations (UN) Conference of the Parties (COP) on climate change}

On 15 December 2019 at the UN COP25 summit in Madrid, world leaders condemned the Australian Federal administration for claiming Kyoto protocol carryover credits to meet 2030 emissions reductions targets [9]. Delegates had argued that such feeble negative targets and cheating responses belied the emerging climate change threats.

\subsection{Black summer bushfires confirm climate crises}

On 2 January 2020, from Cobargo in his bushfire-devastated Australian electorate, New South Wales Parliamentary Minister, the honourable Andrew Constance told of horrific experiences despite the worst of the fire-season remaining. He confirmed the grass roots reality of unprecedented drought, heat, wind, dry fuel load, forest wild fires and black daytime skies. Continental-scale forest, farm, property, business and job losses in the blacksummer fires were then compounded with hazardous smoke choking most capital cities. As parliament resumed on 4 February, Andrew focussed on recovery and forecast Cobargo and Bega to win the "best recovery this planet has ever seen" [10].

\subsection{Unprecedented global biodiversity loss in one summer}

On 10 January 2020, the Australian Academy of Science President, Professor John Shine wrote "the scale of these bushfires is unprecedented anywhere in the world" [11]. They are the largest across any megabiodiverse country and larger than Amazonian and Californian fires in 2019. The world has lost extraordinarily high value biodiversity and over a billion birds, mammals and reptiles to date this Australian bushfire season.

\subsection{Avert climate apocalypse}

On 21 January 2020 at the World Economic Forum (WEF), youth activist Greta Thunberg addressed the Forum at Davos in Switzerland. The 17-year-old spoke beside imagery of a kangaroo bounding from Australian bushfires under an "Averting Climate Apocalypse" banner. She urged global leaders to stop "cheating and fiddling around with numbers". "Our house is still on fire and you're fuelling the flames" [12].

\subsection{Climate alarmists all seeking absolute domination}

A few hours later, the President of the United States of America, Donald Trump, told the Forum to dismiss "the prophets of doom" on climate change as "They are the heirs of yesterday's foolish fortune tellers," and "These alarmists always demand the same thing: absolute power to dominate, transform and control every aspect of our lives" [13].

\subsection{People power can create sustainable markets}

The next day HRH the Prince of Wales queried in his WEF Forum keynote address: "what good is all the extra wealth in the world, gained from business as usual, if you can do nothing 
with it except watch it burn in catastrophic conditions?" [4]. The prince sought forum skills to "lead the world out of the approaching catastrophe". He advised "with consumers controlling an estimated $60 \%$ of global GDP people around the world have the power to drive the transformation to sustainable markets". He proposed ten investment, troubleshooting and innovation actions citing internet and iPhone examples.

\subsection{Doomsday clock nearing apocalypse}

As they do annually, on 23 January 2020, the Bulletin of the Atomic Scientists reset the internationally recognized doomsday clock. The bulletin was founded by Manhattan Project scientists after atomic bombs destroyed Hiroshima and Nagasaki. Considering threats from nuclear war, climate change and disinformation they advanced the doomsday clock time to 100 seconds to midnight, the symbolic apocalypse hour [14].

\section{LEARNING FROM FAILURE}

The aims in this section are to reveal patterns in such narratives limiting success and to expose gaps offering opportunity for action to redress such climate and habitat issues. Qualitative discourse analysis of such narratives was used to assess content meanings.

\subsection{A seasonal situation appraisal}

Most introductory negative narratives conveyed bad news on unprecedented disasters and loss and forewarnings of doom. Accusations of blame, shame and stalling were rife. Words, images and accounts to shock and stun dominated despite risks of demotivating audiences. Positive narratives were uncommon, however, after negative appraisals, two speakers gave positive take-home messages. Words to shock, scold or mock included:

- COP25 world leaders condemning one party of cheating even on feeble targets;

- John reporting globally devastating losses in one season;

- Greta chiding elders for irresponsible fiddling and fuelling apocalyptic flames;

- Donald scorning foolish, alarmist, absolute power-seeking prophets of doom; and

- the doomsday clock set to 100 seconds to midnight, the symbolic apocalypse hour.

\subsection{Positive corollaries for strategic planning}

As negative accounts of loss dominated such public, political and economic communications, it was posited that positive accounts of gain may be more useful to accelerate sustainability. Table 1 shows positive qualities and measures developed as corollaries to detrimental attributes across a strategic planning framework. This produced a set of positive qualities for sustainability planning and regeneration assessment. It depicted new patterns of positive communications with potential to:

- $\quad$ avoid the loss focus, problem-centric negativity, threats, blaming and barriers;

- listen to all sides to understand, engage, persuade or advocate win-win solutions;

- $\quad$ adopt solution-centric positive words, metrics and images to gauge or gain progress;

- use words, artforms and humour to reflect climate and regeneration solutions;

- inspire hope by sighting and faming regenerative steps for overtaking degeneration;

- create, drive and grow investment and work opportunity in sustainable markets;

- inform, educate and transform endemic ignorance, isolation and complacency; and

- disarm opponents, refute disinformation, divert self-interest and inspire advocacy. 
Table 1: Qualities and measures of narratives.

\begin{tabular}{|l|l|l|}
\hline System & Negative detriments & Positive benefits \\
\hline Policy & Control burden, loss and deficit & Control benefit, gain and surplus \\
\hline Purpose & To slow depletion and degeneration & To grow repletion and regeneration \\
\hline Goals & Score on loss in carrying capacity & Score on gain in carrying capacity \\
\hline Scope & Negative to zero; excludes gain & Positive to zero; excludes loss \\
\hline Measures & $\begin{array}{l}\text { Natural asset degeneration and } \\
\text { deficit }\end{array}$ & $\begin{array}{l}\text { Natural asset regeneration and } \\
\text { surplus }\end{array}$ \\
\hline Capacity & Natural assets at current scarcity & Natural assets at former abundance \\
\hline Range & Full loss origin to zero end & Zero origin to full gain end \\
\hline Reach & Approach lower no loss scores & Approach higher full gain scores \\
\hline Catalysts & Scolding; Sticks to abate & Praising; carrots to assert \\
\hline Narratives & Bad news; glass half empty; criticism & Good new; glass half full; praise \\
\hline Games & No win; lose loss; blame; opposition & Win-win; add gain; fame; accord \\
\hline Sightlines & Blind to opposing opportunity & $\begin{array}{l}\text { Sighting beyond opposing } \\
\text { opportunity }\end{array}$ \\
\hline Responses & Ignore, deny, cheat and blame & Agree, declare, honor and emulate \\
\hline
\end{tabular}

\section{MAPPING GAPS IN REFERENCE FRAMEWORKS}

This section considers nested reference frameworks of the UN System of Environmental Economic Accounting (SEEA), International Standards Organisation (ISO) for environmental management systems (EMS), life cycle assessment (LCA), life cycle inventory (LCI), life cycle impact assessment (LCIA) and environmental product declarations (EPD). Qualitative gap analysis was used to examine patterns in framework strengths, weakness, opportunity and threats in quantifying climate and habitat change.

\subsection{Limited reach of references frameworks}

The UN et al. [15] SEEA framework covers benefits from direct use of environmental inputs but excludes indirect benefits from ecosystem services such as water purification, carbon storage and flood mitigation. LCA was designed to reduce industrial pollution and resource depletion which are negative burdens rather than positive benefits. The ISO EMS 14044 standard for LCI and LCIA [16] demands EPDs use ISO 14025 compliant methods to count damage in as well as benefits beyond the system boundary. In the Evah Institute authors' experience these are declared as reduced damages not positive benefits.

\subsection{Applications of invalid LCA metrics}

A letter from 25 non-government organisations (NGOs) across six countries [17] submitted at the ISO TC 207 meeting on EMS at New Delhi in October 2015 called on the ISO to correct methods for LCIA of climate change. It demanded that clearly from the International Panel on Climate Change (IPCC) "we must act with significant emissions reductions in the next 5-10 years if we have any hope of avoiding irreversible climate change. Having a proper set of metrics installed to steer policy in the short amount of time we have to act is critical, as these metrics are essential guides for any type of informed decision making".

It argued that issues with ISO 14044 climate metrics used to asses 300,000 companies' products and systems worldwide included: 
- $\quad$ invalid use of 100-year horizons that ignore imminent climate tipping points;

- effectively ignoring biomass emissions from forest and paper industry sources;

- excluding $60 \%$ of global radiative forcing caused by short-lived climate forcers;

- underestimating by $80 \%$ short-term climate benefits of less methane emissions; and

- overlooking mitigation opportunities in climate hot spots.

\section{DERIVING BALANCED FRAMEWORKS}

The previous section reviewed framework gaps, strengths, weakness and threats considering wellness and security of supply, climate, habitat and people. It reviewed gaps and threats limiting application, opportunity and investment in sustainable markets. This next section contrasts LCIA of damages against life cycle benefit assessment (LCBA) of gains. It reviews LCBA framework, measures and metrics and provides examples.

\subsection{Negative LCIA reach}

Established LCIA applies frameworks and metrics such as Goedkoop et al. [18] report for "ReCiPe" metrics in Europe and Bare [19] reports for "TRACI" metrics in America. Both cover borrowings of natural capital, costs to nature, damages to supply, habitat and health. Both lack positive reach beyond zero to leverage benefit or gain. Fairly typical LCIA is depicted in red in Fig. 1, schematic of LCIA versus LCBA depicted in blue.

\subsection{Positive LCBA reach}

Concomitant positive LCBA depicted in Fig. 1 supplements negative LCIA. The scope extends from zero to positive outcomes in safe operating space within planetary boundaries after Rockström et al. [20]. Regeneration benchmarks are to preindustrial C18 natural capital and wellness benchmarks are to current population longevity as is most appropriate.

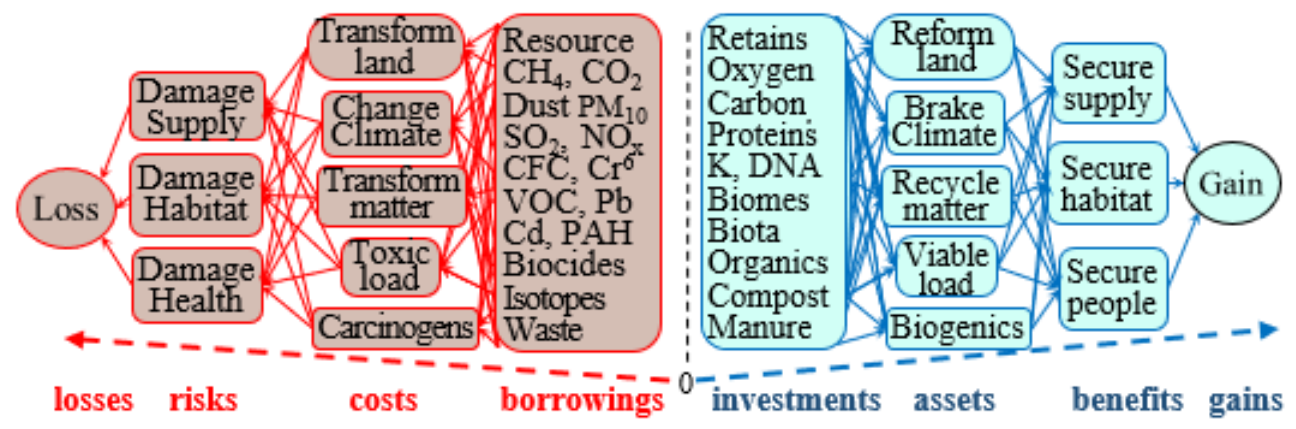

Figure 1: Schematic of LCIA (red) versus LCBA (blue).

\subsection{LCBA framework measures and metrics}

Table 2 shows LCBA metrics for regeneration across natural capital assets derived from Evah Institute frameworks reported by Jones et al. [21] and Baggs et al. [22]. Their strategic purpose is to assess remediation. Such metrics quantify security gains in supply, climate, habitat and people per capita per annum (pppa). These measures of repletion and regeneration also cover potential capacity to return assets to former abundance. 
Table 2: LCBA metrics.

\begin{tabular}{|l|l|l|l|}
\hline Viable & \multicolumn{2}{|l|}{ Security benefit considering } & $\%$ \\
\hline \multirow{4}{*}{ Supply } & Sustainable versus finite & $\mathrm{MJ}$ ncv \\
\cline { 2 - 4 } & Water & Rain versus town water & $\mathrm{kl} \mathrm{rate}$ \\
\cline { 2 - 4 } & Fuel & Renewable versus fossil & $\mathrm{MJ}$ rate \\
\cline { 2 - 4 } & Minerals & Recycled versus primary & $\mathrm{t}$ rate \\
\hline \multirow{4}{*}{ Climate } & Current versus C1750 carrying capacity & $/ \mathrm{m}^{2}$ \\
\cline { 2 - 4 } & Braking & Biomass carbon capacity & $\mathrm{CO}_{2} \mathrm{e}_{20}$ \\
\cline { 2 - 4 } & Banking & Soil carbon capacity & $\mathrm{CO}_{2} \mathrm{e} 100$ \\
\hline \multirow{4}{*}{ People } & Current versus C1750 carrying capacity & $/ \mathrm{m}^{2}$ \\
\cline { 2 - 4 } & Ecosystem & Species richness capacity & rate \\
\cline { 2 - 4 } & Urban & Natural habitat capacity & rate \\
\cline { 2 - 4 } & Aquatic & Marine oxygen capacity & rate \\
\hline & Hale able lifespan years & pp \\
\cline { 2 - 4 } & Air indoor & Indoor oxygen supply & $\mathrm{O}_{2} \mathrm{e}$ \\
\cline { 2 - 4 } & Airshed & Pollution-free clean-air & days \\
\cline { 2 - 4 } & Fecundity & Reproductive survival & rate \\
\hline
\end{tabular}

Climate security gains, for example, arise as carbon drawdown from the atmosphere acts as a brake on climate change. Sunlit photosynthesis in chloroplasts transforms carbon and water into forest, heath, kelp and algae growth. As a consequence, fixed carbon in plant cells walls and roots is banked until drawn out again decades to centuries later.

Again, for example, high-energy ultraviolet rays split oxygen molecules for continuous stratospheric ozone repletion and to brake climate change. Up to $15 \mathrm{~km}$ below from the troposphere surplus photosynthetic oxygen also acts as reserve banks to meet demand for animal respiration and fuel combustion to maximum carrying capacity.

\section{EARLY LCBA CASE STUDIES}

This section reviews Evah Institute reported [23] ISO compliant third party verified LCA methods for certified commercial product ecolabels and Evah Institute developed EPDs. Results of LCIA and LCBA studies with comparable uncertainty and spatiotemporal resolution are shown for a range of applications, damages, benefits and circularity scores.

\subsection{Damages to supply, climate, habitat and people}

Table 3 shows annualised negative damage and loss results $/ \mathrm{kg}$ from cradle to grave LCIA. Forest product results were from Vlieg et al. [24]. Evah reported [28] LCIA of FSC toilet paper $8 \mathrm{~kg}$ pppa typical use over 20 years. Luo et al. [25] reported the results for organic beeswax, propolis and honey.

Table 3: Forest and apiary product damages.

\begin{tabular}{|l|l|c|c|c|c|c|c|}
\hline Loss in & Damage to & Unit & Board & Paper & Wax & Propolis & Honey \\
\hline \multirow{2}{*}{ Supply } & Fossil fuel depletion & $\mathrm{MJ}_{\text {ncv }}$ & 12 & 286 & $<0.01$ & $<0.01$ & $<0.01$ \\
\cline { 2 - 9 } & Mineral depletion & $\mathrm{MJ}_{\text {ncv }}$ & 0.05 & 0.19 & $2.4 \mathrm{E}-03$ & $1.6 \mathrm{E}-03$ & $3.0 \mathrm{E}-04$ \\
\hline Climate & Stratospheric ozone & $\mathrm{kg} R 11_{\mathrm{e}}$ & $3 \mathrm{E}-08$ & $4 \mathrm{E}-08$ & $4 \mathrm{E}-12$ & $3 \mathrm{E}-12$ & $5 \mathrm{E}-13$ \\
\hline Habitat & Ecosystem quality & $\mathrm{m}^{2} \mathrm{pa}$ & $7 \mathrm{E}-05$ & $4 \mathrm{E}-03$ & $4.0 \mathrm{E}-04$ & $3.0 \mathrm{E}-04$ & $5.0 \mathrm{E}-05$ \\
\hline People & Human health & DALY & $3 \mathrm{E}-04$ & $3 \mathrm{E}-02$ & $1.3 \mathrm{E}-03$ & $8.0 \mathrm{E}-04$ & $2.0 \mathrm{E}-04$ \\
\hline
\end{tabular}


6.2 Benefits to supply, climate, habitat and people

Table 4 shows concomitant gains and benefits for those same forest and apiary products and reference units. Current climate braking intensity was rated as $\mathrm{kgCO}_{2 \mathrm{e}} \mathrm{pa} / \mathrm{kg}$ product. Apiary product results outside that study scope are not reported for all outcomes. Beeswax was the top climate brake rated at 21 , then propolis at 15 before particleboard at 10 . The low rated $2 \mathrm{kgCO}_{2 \text { epa }} / \mathrm{kg}$ honey is a wet brew that bees make in wax-capped vats in honeycomb. The $1 \mathrm{kgCO}_{2} \mathrm{pa} / \mathrm{kg}$ tissue used energy intensive wet chemical processing.

\subsubsection{Circularity scores}

Table 5 shows high circularity scores for these products except for water renewal. Making board and paper generated steam not water condensate. Scores were not reported here for honey due to unacceptable uncertainty in evaporation from its high-water content.

\subsection{Negative building system outcomes}

This section reviews Evah Institute LCA [29] of commercial offices per gross floor area (GFA) $/ \mathrm{m}^{2}$ pa. Table 6 shows reduced new tower damage versus business as usual (BAU). The LCA lacks positive outcomes because all environmental damage and natural asset loss from building elements outweighed all positive security benefits and gains from the others. The new tower, nevertheless, earned four green stars from the Australian Green Building Council. This reflects greener as less negative rather than positively sustainable.

\subsection{Positive building system outcomes}

The following Evah Institute developed [30] cradle to grave LCA for an EPD and certified ecolabel covered 60-year use of a $1.35 \mathrm{t}$ garbage diverter in residential high-rise building.

Table 4: Forest and apiary product benefits.

\begin{tabular}{|l|l|c|c|c|c|c|c|}
\hline Viable & Security benefits & Unit & Board & Paper & Wax & Propolis & Honey \\
\hline \multirow{3}{*}{ Supply } & Matter renewal & MJ & 378 & 5476 & \multicolumn{3}{|c|}{ Not reported } \\
\cline { 2 - 8 } & Energy renewal & MJ & 75 & 6296 & \multicolumn{3}{|c|}{ Not reported } \\
\cline { 2 - 8 } & Water renewal & litre & 10 & 16 & 11,900 & 7,900 & 1,300 \\
\hline \multirow{2}{*}{ Climate } & Climate brake & $\mathrm{kg} \mathrm{CO}_{2 \mathrm{e} 20}$ & 47 & 221 & 21 & 14 & 2.2 \\
\cline { 2 - 8 } & Climate bank & $\mathrm{kg} \mathrm{CO}_{2 \mathrm{e} 100}$ & 38 & 590 & 23 & 16 & 2.5 \\
\hline \multirow{2}{*}{ Habitat } & Forestry & $\mathrm{MJ}$ & 452 & 6163 & \multicolumn{3}{|c|}{ Not reported } \\
\cline { 2 - 8 } & Biodiversity & $\mathrm{m}^{2} \mathrm{pa}$ & 0.26 & 483 & \multicolumn{3}{|c|}{ Not reported } \\
\hline \multirow{2}{*}{ People } & Wellness & HALY & $1 \mathrm{E}-4$ & 0.01 & \multicolumn{3}{|c|}{ Not reported } \\
\hline
\end{tabular}

Table 5: Forest and apiary product circularity scores (\%).

\begin{tabular}{|l|l|c|c|c|c|}
\hline Viable & Security benefits & Board & Paper & Wax & Propolis \\
\hline \multirow{2}{*}{ Supply } & Feedstock renewal & 82 & 87 & 100 & 100 \\
\cline { 2 - 6 } & Water renewal & 9 & 0.5 & 100 & 100 \\
\hline \multirow{2}{*}{ Climate } & Climate brake & 181 & 100 & 100 & 100 \\
\cline { 2 - 6 } & Biomass bank & 104 & 38 & 100 & 100 \\
\hline \multirow{2}{*}{ Habitat } & Forestry biota and seed & 73 & 89 & 100 & 100 \\
\cline { 2 - 6 } & Habitat biodiversity & 99 & 99 & 100 & 100 \\
\hline
\end{tabular}


Table 6: New versus BAU building damage results.

\begin{tabular}{|l|c|c|c|c|}
\hline Losses and damages to & Unit & $\mathrm{BAU}$ & $\mathrm{New}$ & $\%$ less \\
\hline Global warming & $\mathrm{kg}_{\mathrm{r}} \mathrm{CO}_{2 \mathrm{eq} 100 \mathrm{y}}$ & 1041 & 874 & 19 \\
\hline Stratospheric ozone & $\mathrm{kg} \mathrm{CFC}_{11 \mathrm{eq}}$ & $1.1 \mathrm{E}-06$ & $9.9 \mathrm{E}-07$ & 10 \\
\hline Photochemical smog & $\mathrm{kg} \mathrm{C}_{2} \mathrm{HO}_{4 \mathrm{eq}}$ & 1.59 & 1.45 & 10 \\
\hline Depletion fossil fuel & $\mathrm{MJ}$ & 647 & 577 & 12 \\
\hline Depletion elemental & $\mathrm{kg} \mathrm{Sb}_{\mathrm{eq}}$ & 2.61 & 2.38 & 9.7 \\
\hline Acidification & $\mathrm{kg} \mathrm{SO}_{2 \mathrm{eq}}$ & 11.9 & 10.4 & 14 \\
\hline Eutrophication & $\mathrm{kg} \mathrm{PO}_{4} \mathrm{eq}$ & 0.52 & 0.46 & 13 \\
\hline Human toxicity & $\mathrm{kg} 1.4-\mathrm{DB}_{\mathrm{eq}}$ & 3.10 & 3.05 & 1.6 \\
\hline Land use change & $\mathrm{m}^{2} \mathrm{pa}$ & $1.1 \mathrm{E}-05$ & $9.6 \mathrm{E}-06$ & 15 \\
\hline Depletion water & $\mathrm{kl}$ & 10813 & 9040 & 20 \\
\hline Ionising radiation & $\mathrm{kBq} \mathrm{U}_{235 \mathrm{eq}}$ & $9.4 \mathrm{E}-12$ & $8.6 \mathrm{E}-12$ & 9.3 \\
\hline Particulate matter & $\mathrm{kg} \mathrm{PM}_{2.5 \mathrm{eq}}$ & 74118 & 65063 & 14 \\
\hline
\end{tabular}

Table 7 shows annualised damages from diverter manufacture versus benefits in space and recyclate supply reported by Jones et al. [21]. Gains $\mathrm{pa} / \mathrm{kg}$ diverter included:

- $\quad$ supply chain reclamation of 1,550 GJ energy and 1,082 Ml potable water;

- habitat vigour without $2,620 \mathrm{~kg} \mathrm{PO}_{4 \mathrm{e}}$ eutrophication or $350 \mathrm{~kg} 1.4 \mathrm{DBe}$ toxicity; and

- wellness from clean air without $0.1 \mathrm{~kg} \mathrm{PM}_{10}$ fume and $0.12 \mathrm{~g} 1.4 \mathrm{DBe}$ toxicity.

Table 7: Diverter damages versus benefits.

\begin{tabular}{|l|l|c|c|c|c|c|}
\hline Viable & Security benefits & Units & Chute & Space & Recycle & Gain \\
\hline \multirow{2}{*}{ Supply } & Energy recovery & $\mathrm{GJ}$ & -667.0 & 110 & 93,530 & 92,973 \\
\cline { 2 - 7 } & Water recovery & $\mathrm{Ml}$ & -5.0 & 76 & 64,877 & 64,948 \\
\hline \multirow{2}{*}{ Habitat } & Climate brake & $\mathrm{t} \mathrm{CO}_{2 \mathrm{e}} 20$ & -100 & $<100$ & 4,000 & 4,000 \\
\cline { 2 - 7 } & Habitat regain & $\mathrm{m}^{2 *} \mathrm{yr}$ & -0.4 & 0.1 & 35 & 35 \\
\hline \multirow{2}{*}{ People } & Hale wellness & years & -6.8 & 0.9 & 457 & 451 \\
\cline { 2 - 7 } & Ozone refill & $\mathrm{g} \mathrm{R} 11_{\mathrm{e}}$ & $<-0.1$ & $<0.1$ & 14 & 14 \\
\hline
\end{tabular}

\subsection{Sustainable building benefits}

This is followed by a review of Evah Institute LCIA and LCBA for an Interpretive Centre in Brisbane described by Baggs et al. [22] The LCA done for the project was first reported by Renger et al. [31] in a paper entitled "Net-positive building carbon sequestration". Subsequently, Cole [32] cited this LCA as a world-first in building design in his editorial for a special issue entitled "Shifting from net-zero to net-positive energy buildings", of the building research and information journal.

Table 8 shows sustainable building benefits for that centre yearly $/ \mathrm{m}^{2}$ GFA. Except for eutrophication that called for mitigation in use, the benefits and natural asset gains outweighed loss. No overall damage arose in:

- climate change from global warming or loss of stratospheric ozone;

- polluting smog, acidification, ionising radiation, particulates or toxicity; and

- depletion of freshwater, fossil fuel, elements or land available for nature. 
Table 8: Sustainable building benefits.

\begin{tabular}{|c|c|c|c|}
\hline Viable & Security benefits & Unit & Gain \\
\hline \multirow{5}{*}{ Supply } & Feedstock retain & MJ & 19.9 \\
\hline & Mineral retain & MJ & 0.1 \\
\hline & Energy renewal & MJ & 1.5 \\
\hline & Matter renewal & $\mathrm{kg}$ & 26.7 \\
\hline & Water renewal & $\mathrm{kl}$ & 30.1 \\
\hline \multirow{2}{*}{ Climate } & \multicolumn{2}{|c|}{ Near term carrying capacity } & \\
\hline & Climate brake & $\mathrm{kg} \mathrm{CO}_{2 \mathrm{e} 20}$ & 42.2 \\
\hline \multirow{2}{*}{ Habitat } & \multicolumn{2}{|c|}{ Current carrying capacity $/ \mathrm{m}^{2}$} & \\
\hline & Ph balance buffer & PRF & 4.7 \\
\hline \multirow{3}{*}{ People } & \multicolumn{2}{|c|}{ Hale able lifespan years $p p$} & \\
\hline & Hale wellness & years & 0.05 \\
\hline & Clean airshed & $\mathrm{kg} \mathrm{O}_{2 \mathrm{eq}}$ & 25.2 \\
\hline
\end{tabular}

6.5.1 Sustainable building landscaping benefits

Table 9 shows annual cradle to grave gains across the centre's interior and exterior wall, roof and curtilage landscaping $\mathrm{pa} / \mathrm{m}^{2}$ GFA. Benefits flow from building green walls acting as a climate bank. Oxygen generation enables stratospheric ozone refill adding to climate and habitat security as well as wellness of people.

Table 9: Built landscaping benefits.

\begin{tabular}{|l|c|c|c|c|c|}
\hline Elements & Area $\mathrm{m}^{2}$ & Climate banking & Units & Oxygen airshed & Units \\
\hline Green walls & 5,530 & 6.6 & $\mathrm{CO}_{2 \mathrm{e} 100}$ & 4.8 & $\mathrm{~kg} \mathrm{O}_{2 \mathrm{eq}}$ \\
\hline Landscaping & 19,600 & 2.8 & $\mathrm{CO}_{2 \mathrm{e} 100}$ & 2.1 & $\mathrm{~kg} \mathrm{O}_{2 \mathrm{eq}}$ \\
\hline Atriums & 800 & 1.5 & $\mathrm{CO}_{2 \mathrm{e} 100}$ & 1.1 & $\mathrm{~kg} \mathrm{O}_{2 \mathrm{eq}}$ \\
\hline Rooftops & 710 & 1.4 & $\mathrm{CO}_{2 \mathrm{e} 100}$ & 1.0 & $\mathrm{~kg} \mathrm{O}_{2 \mathrm{eq}}$ \\
\hline
\end{tabular}

\section{DISCUSSION OF STRATEGIES AND SOLUTIONS}

While the paper focussed on LCA, the same principals of communication apply to most city, polity and economic planning tools currently used to reduce unsustainable outcomes.

\subsection{Negative communications culture}

Criticism and blame headlines appear aligned to combative disinformation. Negative narratives are commonplace and evident in book titles such as "Cannibals with Forks" and the global youth movement "Extinction Rebellion". In a world-wide loss and blame culture the authors argue that climate and habitat regeneration depend on addressing:

- misunderstood counterintuitive earth-system feedback-looped interactive effects;

- ageist bias affecting youth with climate change and extinction legacy locked-in;

- ecologically-blind sciences, economics, polity and law not yet addressing ecocide;

- acquisitive intensive lifestyles underpinning inequitable and unsustainable markets;

- cumulative self-interest against common good that is stalling climate crisis summits;

- $\quad$ end-use focus ignoring cradle to fate damage and depletion of natural assets; and

- urban ecophobia excluding wildlife, marsupials, birds, bees and worms as vermin. 


\subsection{Damage focussed frameworks}

Discourse analysis of public communications and core references frameworks showed reliance on negatives narratives and metrics. All frameworks sampled exclude critical positive gains in security of supply, climate, habitat and people wellness. Their negative range stops at zero damage to supply, climate, habitat and people. Their ignorance of positive ideation beyond zero loss creates chasms for assessment in sustainable markets.

\subsection{Negative business culture}

Many companies use negative environmental assessment frameworks and LCA standards that ignore highest short-term climate risks. EPD metrics often exclude IPCC factors for short term damaging carbon emissions and beneficial sequestration but not biogenic methane emissions. This acts as a barrier to climate and habitat recovery. Entities upholding such barriers to sustainable markets profit from tragedies of the commons.

\subsection{Positive solutions culture}

Positive calls to action across industry, political and social networks can synergise initiatives and invite participation from wild-lifers, regenerators, sapling armies, climate bankers, carbon jesters and honourable ancestors. Positive narratives are needed in:

- $\quad$ education to learn earth-system feedback-looped interactive wizardry and apps;

- ethical investment in climate braking and regeneration outcomes;

- eco-wise science, economics, polity and law to address ecocide and eco-loss;

- trending dematerialised renewal lifestyles securing climate and equity;

- promoting wildlife corridors and care for native animals, birds, bees and worms;

- drones and apps for mapping ecophylic roads, towns and cities; and

- developing narratives to promote engagement in repletion and drawdown initiatives.

\subsection{Distinctive competitive advantage}

A distinctive competitive advantage of LCBA is that for the first time it can balance LCIA. This allows systematic quantification for reporting both losses and gains essential for investment in sustainable markets. It can also clarify unsustainable market activity.

\section{CONCLUSIONS}

Negative narratives do not motivate people to avert the climate and extinction crises. The unsustainability focus of core frameworks that influence policy remains blind to solutioncentric sustainability measures. LCIA methods exclude IPCC factors of highest short-term climate risks. Positive frameworks, strategies and quantitative methods to address ecological remediation cover security of supply, climate, habitat and wellness. New terms and metrics are needed to inform science, industry and community initiatives in sustainable markets. Case studies comparing LCIA and LCBA showed accounting beyond zero loss to include gains in security of supply, climate, habitat and people. Positive narratives and measures are considered vital to provide new capability, tools and applications to assess benefits; initiate, cover and deliver balanced sustainability analysis for sustainable markets; power to create traction in sustainable market initiatives and investments; and uphold discretion that ensures unbiased and equitable gains in sustainable outcomes. 


\section{RECOMMENDATIONS}

Espousing benefits and counting gains to engage people is an imperative. Compelling climate and habitat security narratives around carbon drawdown are needed at this critical time in human development. Theoretical and practical transitions are vital to extend negative perspectives beyond zero damage and loss to bridge barriers to positive viewpoints with sightlines to discern future benefits and gains. Beyond reducing pollution and degradation, inhabitants of a sustainable world must regenerate natural assets. Justification of investment in sustainable markets calls for quantification of benefits and gains of natural assets as much as damages and losses.

\section{REFERENCES}

[1] United Nations Environment Programme (UNEP), Global Environment Outlook 6: Healthy Planet Healthy People, 2019. www.unenvironment.org/resources/globalenvironment-outlook-6. Accessed on: 5 May 2019.

[2] United Nations Framework Convention on Climate Change, Speeches and statements at COP 25. https://unfccc.int/process-and-meetings/conferences/un-climate-changeconference-december-2019/speeches-and-statements-at-cop-25. Accessed on: 9 Jan. 2020.

[3] Stocker, et al. (eds), Climate Change: The Physical Science Basis, Chapter 8: Anthropogenic and Natural Radiative Forcing, IPCC AR5, Cambridge University Press: Cambridge, pp. 659-740, 2013.

[4] HRH Charles, Prince of Wales, Keynote to WEF, Davos, Switzerland, 21 Jan. 2020. www.princeofwales.gov.uk/prince-wales-delivers-keynote-address-world-economicforum-davos-switzerland. Accessed on: 4 Feb. 2020.

[5] Dunlap, R.E. \& McCright, A.M., Challenging climate change the denial countermovement. Climate Change and Society: Sociological Perspectives, eds R.E. Dunlap \& R.E. Brulle, Oxford University Press: Oxford and New York, pp. 300-322, 2015. DOI:10.1093/acprof:oso/9780199356102.003.0010.

[6] Commonwealth Science and Industrial Research Organisation (CSIRO), What science tells us about fugitive methane emissions from unconventional gas? 10 Sep. 2019. https://gisera.csiro.au/factsheet/fugitive-methane-emissions/. Accessed on: 2 Jan. 2020.

[7] Workman, D., World's top exports: Coal exports by country, 2019. www.worldstopexports.com/coal-exports-country/. Accessed on: 16 Jan. 2020.

[8] Climate Council, What the frack? Australia overtakes Qatar as world's largest gas exporter, 18 Jan. 2019. www.climatecouncil.org.au/australia-worlds-largest-gasexporter/. Accessed on:16 Jan. 2020.

[9] McManis, A., COPing it in Madrid: Why Australia's stance at COP25 was condemned. www.internationalaffairs.org.au/australianoutlook/coping-it-in-madrid-whyaustralias-stance-at-cop25-was-so-widely-condemned/. Accessed on: 16 Jan. 2020.

[10] Sanda, D., NSW MP opens up about bushfire trauma, The Canberra Times. www.canberratimes.com.au/story/6614522/nsw-mp-opens-up-about-bushfire-trauma/ ?cs $=14231$. Accessed on: 4 Feb. 2020.

[11] Shine, J., The Australian bushfires: Why they are unprecedented, Australian Academy of Science. www.science.org.au/news-and-events/news-and-media-releases/ Australian-bushfires-why-they-are-unprecedented. Accessed on: 2 Feb. 2020.

[12] Thunberg, G., World Economic Forum (WEF), Davos, Switzerland, 21 Jan. 2020. www.weforum.org/agenda/2020/01/greta-thunberg-davos-message-climate-change/. Accessed on: 4 Feb. 2020. 
[13] Trump, D., Address to WEF, Davos, Switzerland, 21 Jan. 2020. www.weforum.org/agenda/2018/01/president-donald-trumps-davos-address-in-full8e14ebc1-79bb-4134-8203-95efca182e94/. Accessed on: 4 Feb. 2020.

[14] Knowles, H. \& Ohlheiser, A., Doomsday clock is 100 seconds to midnight, 23 Jan. 2019. www.washingtonpost.com/weather/2020/01/23/doomsday-clock/. Accessed on: 6 Feb. 2020.

[15] United Nations (UN), European Commission, Food and Agriculture Organisation of the UN, International Monetary Fund, Organisation for Economic Cooperation and Development and the World Bank, System of Environmental Economic Accounting (SEEA) 2012 - Central Framework, United Nations: New York, p. 13, 2014.

[16] International Standards Organisation (ISO), ISO 14044:2006 EM: LCA: Requirements and guideline for data review: LCI; LCIA, Interpretation results, ISO: Geneva, 2006.

[17] Sierra Club, BC Canada et al., Letter to the ISO-TC-207 Secretariat, 10 Sep. 2015.

[18] Goedkoop, M. et al., RECIPE 2008 Method, Dutch Ministry of Housing, Spatial Planning and Environment: The Netherlands, 2008.

[19] Bare, J.C., Tool for the Reduction and Assessment of Chemical and Other Environmental Impacts (TRACI), V 2.1 - User Manual, EPA/600/R-12/554, 2012.

[20] Rockström, J. et al., Planetary boundaries: Exploring the operating space for humanity. Ecology and Society, 14(2), p. 32, 2009.

[21] Jones, D.G., Vlieg, A.M.M., Ashar, S. \& Baggs, D.M., Positive LCA factoring planetary boundaries. Proceedings of the 27th Society of Environmental Toxicology and Chemistry (SETAC) Conference, Brussels, Belgium, pp. 231-232, 2017.

[22] Baggs, D.M., Jones, D.G., Vlieg, A.M. \& Ashar, S., Driving "beyond LCA" metrics for net positive cities. Proceedings of the 27th Annual SETAC Conference, Brussels, Belgium, pp. 167-168, 2017.

[23] The Evah Institute, Product category rules: Methodology for LCA and EPDs. www.evah.com.au/our-epds.html, pp. 1-20. Accessed on: Jun. 2019.

[24] Vlieg, A.M.M., Jones, D.G. \& Ashar, S., Forest product LCA: Carbon form, fire, fuel and fate rules. Proceedings of the 27th Annual SETAC Conference, Brussels, Belgium, p. 52, 2017.

[25] Luo, J., Jones, D.G. \& Vlieg, A.M., Hive environmental health for bee product in personal care. Proceedings of the Australasian SETAC Conference, Gold Coast, 6 Sep. 2017.

[26] Jones, D.G., Vlieg, A.M., Baggs, D.M., Biaz, O. \& Bortsie, N., Novel wood LCA and EPDs. Proceedings of the 29th Annual SETAC Conference, Helsinki, pp. 255-256, 2019.

[27] The Evah Institute, Laminex: Trade essentials particleboard flooring EPD, Global GreenTag: Brisbane, pp. 1-14, 2018.

[28] The Evah Institute, Toilet tissue EPD, Global GreenTag: Brisbane, pp. 1-14, 2018.

[29] Jones, M.O. \& Jones, D.G., GreenStar project commercial office building LCA verification report (confidential), Ecquate Pty Ltd: Australia, 25 Jun. 2018.

[30] The Evah Institute, Recycling eDiverter, Global GreenTag: Brisbane, pp. 1-14, 2017.

[31] Renger, B.C., Birkeland, J.L. \& Midmore, D.J., Net-positive building carbon sequestration. Building Research and Information, 43(1), pp. 11-24, 2015.

[32] Cole, R.J., Net-zero and net-positive design. Building Research and Information, 43(1), pp. 1-6, 2015. DOI: 10.1080/09613218.2015.961046. 